\title{
Radical Animism and the Geontological: An Ecocritical Reading of Patrick Chamoiseau's Le vieil homme esclave et le molosse
}

\author{
James Boucher \\ Rutgers University-Camden
}

\section{Introduction}

The inclusiveness of Patrick Chamoiseau's vision of humanity in his thoughts on créolité as a(n) (interpretive) model for the future of the species infuses the entirety of his oeuvre, from his autobiographical works and theoretical texts, to his novels. The movement of créolité promotes the exploration of the past with an eye to future enunciations of communitarian identity writ large. In articulating precisely how the coming together of human diversity in the (French) Caribbean functioned and continues to function in relation to the rest of the world, the créolistes theorize a pan-créolité that seeks to include everyone.

Nous sommes tout à la fois, l'Europe, l'Afrique, nourris d'apports asiatiques, levantins, indiens, et nous relevons aussi des survivances de l'Amérique précolombienne. La Créolité c'est «le monde diffracté mais recomposé», un maelström de signifiés dans un seul signifiant : une Totalité (Barnabé et al. 27).

Seeking to recognize the Self in the Other and the Other in the Self is a practice of which one can readily locate evidence within the theoretical writings of Chamoiseau, as well. Claiming appartenance to several ethnic categories is just the primary move in the development of a more radical form of créolite that emerges in the author's fictional works, however. In the novel Le vieil homme esclave et le molosse a much broader perspective on subjectivity materializes, what he calls une spécificité ouverte (Barnabé et al. 27). Chamoiseau advocates both local anchors of belonging in contemporary temporalities and geographies, but also remains creatively open to transcontinental, transcultural, and trans-historical expressions of identity that continue to influence and inhabit modern creoles of all origins in the Antilles. Building on this initial inclusivity which merges the full diversity of human categories is a deeper, more radical animism that attempts to open up onto a comprehensive vision of humanity and the environment including not only the human but also non-human categories of existents: animal and vegetal. This study investigates the ecocritical potentialities of the (re)valorizing of all categories of being in Le vieil homme esclave et le molosse. The non-human is a ubiquitous site of subjectivity and voice in the works of the 
marqueur de paroles, generally, but especially in the case of Le vieil homme esclave et le molosse $e^{1}$.

This emphasis on non-human subjectivities is a fertile site from which a coherent ecological vision can arise. The environmentalist voice is often symbiotically and symbolically imbricated in and inextricable from Chamoiseau's vision of the human category. Le vieil homme esclave et le molosse in particular demonstrates how one can successfully create a humanist and environmentalist message that avoids the pitfalls of many (deep) ecological discourses that make the move of simply replacing asymmetrical human exceptionalism associated with the excesses of late liberal capitalism with an anti-humanist idealization of a mythically sacralized Nature. No viable solutions to the enormous environmental challenges that we will all face in the twentyfirst century and beyond can be adequately addressed without also simultaneously addressing the pressing questions of human suffering, identity, and the inequalities of the current global economic regime. In this novel, both buman créolité and environmentalist créolité are articulated in parallel, in conversation and convergence, as a unified discursive technique and aesthetics. This is the uniqueness of postcolonial ecocritical texts that insist that all peoples are equally part of the natural world, all equally called to account and to action with regards to the environmental crisis, while also not denying how certain peoples and modes of thought have varying impacts on the environment. Such a methodological viewpoint:

...requires a broader ecological conception of natural-cultural relations on several different levels - including the planetary level - than has tended to be the case in much ecocriticism until now. Postcolonial approaches remain helpful here in ensuring that the ongoing struggle for global environmental justice is pursued; that cultural differences are taken into account in building the bioregional models of sustainability and resilience; and that new ways of thinking about the human - also thinking beyond the human - are developed that recognize the imbrication of social and ecological factors... (Huggan and Tiffin, Preface).

This global vision of human and environmental issues resonates particularly in Chamoiseau's dual créolité which calls for coexistence and cooperation, reciprocity and solidarity across divisions staunchly defended in ideologies of imperialism and late liberal capitalism. The synergy of buman and environmentalist créolités additionally includes categories often neglected in Western worldviews, what Huggan and Tiffin refer to as 'thinking beyond the human'. In Chamoiseau's

${ }^{1}$ Marqueur de parole is a reference to the writer or narrator Patrick Chamoiseau. The author selfattributes this moniker over many different texts. An alter-ego or simply an insistence on the presence of the writer in his fiction, it is a significant indication as to how Chamoiseau envisions the role of the artist in the literary enterprise. 
fiction, metaphysical elements are embedded within materialities and subjectivites that are often relegated to silence and oblivion in the discourses of empiricism, positivism, and late liberalism. Chamoiseau's radical rethinking of the (human) world and of the environment presents a possible doorway to a more productive way of thinking about the human and the non-human, the living and the non-living world(s) alike.

In this article, I demonstrate how radical animism merges with what Elizabeth Povinelli labels the geontological in order to create an ecocritical conceptualization of the world. Rather than separate, distinct visions of materialities, the geontological in Le vieil homme esclave et le molosse is an extension of radical animism which allows for a broader inclusion of all existents. As the text advances, Chamoiseau's animism shifts, moving into the realm of the geontological via the technique of assemblage. Povinelli maps out the evolution from animism to the geontological in the terms of power formations. In Geontologies: A Requiem to Late Liberalism (2016), the turn to geontology is characterized by the obsolescence of what Foucault theorizes as biopower and the biontological. According to Povinelli, it is the global climate crisis that requires a new approach, one that comprehensively incorporates inanimate matter into humanity's understanding of the subject. The curtain is now opening onto a:

$[\ldots]$...new drama, not the drama of life and death, but a form of death that begins and ends in Nonlife-namely the extinction of humans, biological life, and, as it is often put, the planet itself-which takes us to a time before the life and death of individuals and species, a time of the geos, of soulessness (sic) (Povinelli, Geontologies 8).

Chamoiseau's novel Le vieil homme esclave et le molosse urges the reader to valorize the imbrication of the living and the non-living by understanding how the animate is, has always been, and will always be dependent on the inanimate. The author accomplishes this refusal of the Cartesian dualism that has dominated western thought for centuries through an increasingly radical animism which includes all elements of the biological (human, animal, vegetal), before finally illustrating the subjectivity (intrinsic value) of the non-living. The culmination of Chamoiseau's radical animism is a turn to the geontological when the African and the Amerindian, the animate and the inanimate, are united through the assemblage of a stone inscribed by Caribs and the (meta)physical remains of the novel's protagonist. This move to the geontological presents a model that if espoused might forestall the worst in terms of the climate change predictions that the scientific community assures us cannot be prevented without concerted global cooperation.

\section{Radical Animism}


One of the fundamental ways in which Chamoiseau gives voice to a more diverse world, one populated with subjectivities where Western knowledge often finds only mute nature or abandoned materiality is through the expression of a radical animism. In Philippe Descola's typology of human ontologies, the animist is described as attributing humanity to the non-human in a systematic way, thereby populating the non-human world with the human, that is, seeing the Self in the Other. Descola succinctly defines animism as, "l'imputation par les humains à des non-humains d'une intériorité identique à la leur" (229). To provide an example from the animist perspective of Amerindian ${ }^{2}$ peoples of the Amazon Basin, the tapir is actually a human who lives an entirely human social life, with a wife and children, including the whole range of relationships from inimical to amical with other tapirs and other species. However, the tapir dons the outward physical form of the animal known as tapir in its interactions with humans (Descola 242-4). For the animist category of worldview, subjectivity and humanity is interiorized and naturalized in the Descolian taxonomy. Humanity and human subjectivity exist in fully developed form within not just the human category, but in other categories of existence as well. In the example of the tapir, another animate animal is granted human subjectivity.

The animal is also the site where Chamoiseau's radical animism becomes most apparent in Le vieil homme esclave et le molosse. The plantation owner's molosse plays a subject role linked to the category animal, but one that also symbolizes the békês role in the forging of Martinican identity, society, and history ${ }^{3}$. The molosse embodies duality and subjectivity in many ways. Not only animal and béké, it is also violence and reconciliation, mastery and servitude, subject and object, perpetrator and victim, nature and culture. This duality is redolent of the polysemous propensity evident in Chamoiseau's writing, but also an indication of how (semantically and symbolically) absorbent the category of animal can be, especially within the framework of Chamoiseau's radical animism. I delve deeper into the ontological stakes of the author's representation of the animal via the molosse below. The other 'absorbent' existent around which Le vieil homme esclave et le molosse orbits is Slave Old Man himself.

\footnotetext{
${ }^{2}$ In this article I will use the terms Amerindian, Native, and Indigenous interchangeably to refer to the original indigenous inhabitants of the Americas more generally, and the Carib peoples of Martinique more specifically in the context of Chamoiseau's Le vieil homme esclave et le molosse. I have chosen to do so as a convenient stylistic move, one that helps to avoid the repetition of the same lexical items throughout the piece. There are, however, important differences between the three terms, that nonetheless, for the sake of simplicity, I choose not to engage with here. 3 Béké is a term used in Martinique and Guadeloupe to refer to the White planter class. As an instrument of the violence of the chattel slavery system, the molosse is explicitly linked to the hierarchy of racial domination at its core.
} 
The ontological relationship between the molosse and the African slave, one forged in the movement and violence of the Middle Passage is illustrative of Chamoiseau's radical animism. It is an existential entanglement, a shared history, destined to exist and persist in the geographies of the Caribbean, namely Martinique. According to Chamoiseau, it is primarily concrete physical violence that forges a metaphysical connection between the animal and the human in the context of the destructiveness of the Middle Passage. The author tells us that the animal, the molosse is capable of creating connections across physical and metaphysical categories. The molosse serves as a bridge first between slaver and slave, and then between béké and slave, "Le molosse exprimait la cruauté du Maître et de cette plantation.” (Chamoiseau, Le vieil homme, Chapter 2)

One metaphor employed by Chamoiseau to speak of the porous, shapeshifting nature of the molosse is to label him a monster. While both the African and the molosse share the experience of diaspora, it is only the hound that is branded as monstrous. The hound is at once the embodiment of both the victims and the perpetrators of the violence and trauma of abduction, of the Middle Passage, as well as the sustained cruelty involved in the maintenance of a system of chattel slavery in the Caribbean:

Le molosse était un monstre. Il avait voyagé lui aussi en bateau, durant des semaines d'une sorte d'épouvante. Lui aussi avait éprouvé ce gouffre du voyage en vaisseau négrier... ...À l'instar de tous ceux qui s'en venaient aux îles, le molosse avait subi le roulis continuel de la mer, ses échos insondables, son avalement du temps, sa déconstruction irrémédiable des espaces intimes, la lente dérade des mémoires qu'elle engendrait (Chamoiseau, Le vieil homme esclave et le molosse Chapter 2).

The ontological disaggregation that Chamoiseau associates with the Middle Passage does not spare other categories of existents. Here, the hound is changed by the experience in much the same way as the slaves. Henceforth, they are destined to share a (hi)story that is marked by the trial of the Atlantic Ocean. The ocean itself is implicated in this process of transformation. The ocean as existent is imbued with an agency of its own; it is held accountable for the terrible and irreparable deconstruction of the intimate spaces of both the victims and perpetrators through a linkage with the unspeakable acts of violence of the Middle Passage. Oceanic metaphors are peppered throughout the novel, becoming established as a narrative motif expressed via an up and down movement redolent of the action of ocean waves. Violence forges a physical and metaphysical connection between human and animal that is developed further by Chamoiseau when he recounts the escape of Slave Old Man and his subsequent pursuit by the molosse. Violence also forges an ontological bond between human, animal, and inanimate existents, such as the sea. In the context of the Middle Passage, this is expressed not only through a link between the 
slave trade and its animate corollaries along with the Atlantic Ocean, but also through one with the slave boat itself.

After narrating a variety of slave responses to the trauma of the Middle Passage, up to and including suicide, it is through an act of metonymy that the slave boat, in contact with both the Atlantic Ocean and the humans and animals in its hull and on its decks, shifts from inanimate object or non-life (a typical categorization from a positivist Western perspective), to animate subject or life (a point of view that resembles both traditional African and Amerindian viewpoints):

Seul le vaisseau lui-même, par son rythme de vagues, la majesté claquante des hautes voilures, semblait vivre et faire vivre ces captifs. Le molosse était un monstre car il avait connu cette effondrée-là (Chamoiseau, Le vieil homme esclave et le molosse Chapter 2).

In this formulation, the slaves and the hound are bound physically and ontologically to the ocean through the metonymic vehicle of the slave ship. If the molosse embodies the materialization of the author's insistence on a lack of clear boundaries between the human and the animal, then the animated slave ship is an example of the blurring of distinctions between human subject and inanimate object. Metonymy is particularly apropos as a narrative device in the context of promoting this type of description entailed by Chamoiseau's radical animism. Metonymy, by its very nature, lends itself to a muddying of physical and metaphysical boundaries. It facilitates a relaxing of the strict classifications associated with rationalist, positivist discursive regimes, while creating possibilities for the evolution of practices of interaction between existents. This evolution of behaviors between existents is most readily visible in the coming together of the eponymous characters near the end of the text.

After a long chase and battle ensues between the hound and Slave Old Man, an unexpected transformation occurs that is represented textually in the same fashion as the ontological commingling seen in Chamoiseau's descriptions of the Middle Passage. Rather than fulfilling the function assigned to it by the béké (killing his quarry), the hound performs a remarkable gesture of connection: it licks Slave Old Man's face as he lies dying.

Il [le molosse] écarta la masse de ses instincts où sommeillaient des conduites à tenir. Il se livra à ce qu'il recevait. Il regardait comme, du haut d'un abîme, on regarde le crépuscule d'un astre, ou le grand-œuvre de sa naissance. Il ne savait pas trop. Le monstre s'approcha encore de l'être [le vieil homme esclave] et, sans trop savoir pourquoi, avec la conviction dont il était capable, se mit à le lécher. Il ne léchait pas du sang, ou de la chair, ou de la sueur de chair. Il ne prenait pièce goût. Il léchait. C'était l'unique geste qui lui était donné (Chamoiseau, Le vieil homme eslcave et le molosse, Chapter 6). 
This decisive moment of the text is one that shatters the reader's expectations. The hound is meant to do the Master's bidding and devour Slave Old Man, but Chamoiseau, as is often the case in this novel, opens up a space which allows a new type of non-violent intercommunication to occur, one based on a radical animism founded on recognition in finitude, on reciprocity in existence. The hound opens itself to the world around it, 'giving himself over to what he was receiving'. Chamoiseau's brand of radical animism is apparent here. The hound is a full subject with the capacity to interact with the world by recognizing the Same in the Other in much the same way that Chamoiseau represents Slave Old Man's interactions with the natural world. The hound expresses the metaphysical recognition of Slave Old Man within the confines of his (physical) limitations. The act of licking to manifest care is the only gesture available to the dog. This limited range does not, however, diminish the significance of the action.

In her work on technology and animals, Donna Haraway has repeatedly called into question the epistemological walls that science and culture erect between humans and other types of existents. The culmination of the hound's hunt of Slave Old Man, the dog's licking of the human's face as the latter is dying, is an example of the linkage that Haraway theorizes between the terms 'companion' and 'species'. She tells us,

To hold in regard, to respond, to look back reciprocally, to notice, to pay attention, to have courteous regard for, to esteem: all of that is tied to polite greeting, to constituting the polis, where and when species meet. To knot companion and species together in encounter, in regard and respect, is to enter the world of becoming with, where who and what are is precisely what is at stake (Haraway 19).

For Haraway, existence is always multiple and always in flux. The connection between the human and the animal is one that is continually constitutive of both categories. This is Haraway's intention when she uses the term 'becoming with', a foundational concept of how she views humanity in communication/coevolution with non-human animals. The ontological and physical, the valuing of the Other in the same terms as the Same, is 'at stake' in Chamoiseau's novel when predator and prey are united in a mutual regard for one another that transcends the violent histories of slavery and extractivism. The choice of the hound to abandon violence in favor of what Haraway calls 'esteem', demonstrates Chamoiseau's radical animism. The hound is capable of culture and knowledge, endowed with the necessary agency to participate in and contribute to the creation of a new polis, one based on an equitable dispensation without regard for the categorizations of existents as they are articulated in late liberal capitalism. 
Why is Chamoiseau's radical animism so significant? I propose a dual response. Firstly, the affinity posited by the author between the African diaspora and the genocide perpetrated on Amerindian peoples of the Caribbean (discussed in detail below), although by no means exceptional in Caribbean literature generally, is expressed through a unique lens, that of radical animism. This narrative process has critical and creative potential to unlock a more profound understanding of identity and environment in the (literature of the) Caribbean. This could be perhaps labeled as the 'post-colonial' side of the equation.

Secondly, within the articulation of Chamoiseau's radical animism, metonymy is an effective narrative technique that resists the categorization of everything deemed non-human to the realm of the non-existent. Human, and often a hierarchical vision of humanity itself constricts the category to include only certain humans, becomes the sole representative of life in any meaningful sense. Whereas, the non-human and inanimate (as well as marginalized human groups) are related to non-life. Western definitions and naming are often employed to devalue many categories of existents that do not meet the reductive criteria of human. These considerations must necessarily be taken into account in any attempt at an ecocritical reading or interpretation of Chamoiseau's work, especially Le vieil homme esclave et le molosse.

It is through narrow definitions of non-human existents that widespread destruction of the environment is euphemized, marginalized, justified, and simply ignored or forgotten. This second factor regarding the importance of Chamoiseau's radical animism through the metaphorical lens of metonymy might be best characterized as the 'ecocritical' side of the equation. Both sides, the 'post-colonial' and the 'ecocritical', are symbiotic and inseparable, much in the same way as the blurred existential mélanges that people Chamoiseau's fiction. The same processes of categorization that allow for the exploitation of the environment based on its inherent non-humanness, are mirrored in the imperialism of slavery, the genocides of the Americas, and the generalized subjugation of all types of existent that haunts Chamoiseau's oeuvre. Late liberal capitalism's system of categorization gives the lie to radical animism's overtures to all categories of existents in the name of an exclusively Eurocentric form of anthropocentrism, one that stakes a claim for the White European (male) as the sole existent fit to occupy the central position at the apex of the hierarchy of existents, that of (human) subject. This exclusivity stands in stark contrast to the inclusivity of Chamoiseau's radical animism which is offered as a counterdiscourse to the naturalized classifications of the West. In the next section, I 
explore Chamoiseau's animism more profoundly by examining its specifically geontological aspects through the concept of assemblage.

\section{Assemblage and Geontology}

I have thus far been referring to the physical and metaphysical connections proposed by Chamoiseau between existents of all types as a form of radical animism. One critical component of the author's radical animism is based upon the distinction drawn in Western thought between animate and inanimate, between living and dead. In many indigenous worldviews, the distinction between animate and inanimate, living and dead, human or animal and landscape is much less dichotomous. For Indigenous peoples, the inanimate-animate binary can often be much more complex and does not exist in the same manner that it has often been taken for granted in the West since at least the early modern period $^{4}$.

Attempting to go beyond the Foucauldian vision of the West's obsession with making live in an anthropocentric system of biopolitics, Elizabeth Povinelli turns to Aboriginal Australian visions of the land and other natural occurrences (meteorological phenomena, for instance) to draw a distinction between Western modernist conceptions of the natural world in conversation with more ontologically inclusive views espoused by many Indigenous peoples. This broad view of what constitutes agency, vitality, life, and subjectivity is reminiscent of Chamoiseau's radical animism.

Why is the distinction between living and dead, inanimate and animate so crucial? One of the implicit functions of the definition of life and non-life in Western worldviews is to isolate that which has rights along the familiar dividing line of subject/object. Non-life is relegated to the object realm, which lacks agency/subjectivity and, therefore, a right to continue to exist as such. In epistemological and juridical terms, the geontological is of the utmost importance, because these are distinctions that may determine the ability to protect natural environments and resources in the face of pressures to further exploit and destroy existents of all kinds. In spite of the rise of international environmentalist demands for greater protections of the environment beginning in the West in the 1960s, there is much evidence that exploitation of the natural world has increased and is likely to continue trending upward rather than substantially declining in the coming decades. The industrialization and economic development of countries such as China and India are often cited

${ }^{4}$ Descartes' separation of human and animal, soul and body, mind and matter, also known as Cartesian dualism is often considered a foundational moment in this regard. This philosophical concept is explained in Discourse on Method (1637). 
persuasively as indicative of expanded destruction of the environment in the twenty-first century (and beyond). In Amitav Ghosh's monograph The Great Derangement: Climate Change and the Unthinkable he argues for an historicization of the global climate crisis that emphasizes the deleterious effects, not only of capitalism, but also of "empire and imperialism" (87). His position inherently calls for a reconfigured analysis that considers the excesses of (settler) colonialism, slavery, and economics as concomitant factors in the destruction of the environment, as well as in any possible solution. In this context, the importance of Povinelli's work on what she calls 'a set of discourse, affects, and tactics used in late liberalism to maintain or shape the coming relationship of the distinction between Life and Nonlife...', cannot be underestimated from an ecocritical perspective (Geontologies: A Requiem for Late Liberalism 4).

Povinelli astutely situates the present moment as a turning point, one that will be critical for any endeavor to protect connections between people and place or the environment more generally. Povinelli claims that, '....as the previously stable ordering divisions of Life and Nonlife shake, new figures, tactics, and discourses of power are displacing the biopolitical...' (Geontologies: $A$ Requiem for Late Liberalism 4). This same transition, from anthropocentric biopolitics to ecocentric geontopolitics, is grappled with by Chamoiseau in Le vieil homme esclave et le molosse.

Chamoiseau's radical animism is politically and geontologically inclusive ${ }^{5}$. Prescient of shifts occurring in multiple domains, Chamoiseau questions the foundations of the market truth of late liberal capitalism through the act of joining together existents of all types in meaningful assemblage. Assemblage is a key concept in many Indigenous Weltanshanngen, as well as in Povenelli's theorizing of the geontological. Through the designation of non-life, late liberal capitalism determines value in a restrictive/reductive manner, often ignoring or marginalizing outlooks which valorize the polyvalent focus of assemblage. As Povinelli states:

Critical theory has increasingly put pressure on the ontological distinctions among biological, geological, and meteorological existents, and a posthuman critique is giving way to a post-life critique, being to assemblage, and biopower to geontopower (Geontologies: A Requiem for Late Liberalism 14).

Many of the turns that critical theory has taken in the last decades of the twentieth and the first decades of the twenty-first centuries aim to decenter humanity, and thereby anthropocentric economic imperatives. Geontological

${ }^{5}$ The geontological refers to the invigorated importance of how living and non-living are defined politically, juridically, and economically. As well as a re-imagining of the past (histories of Amerindian genocide, African enslavement, and European development in the Americas), Chamoiseau's novel speaks to the crisis of global warming in the present. 
perspectives transcend more limited (but very crucial) theoretical disciplines, such as animal studies, by promoting a broader animist understanding of all things living and non-living as worthy of subject status. The shift that Povinelli pinpoints between being and assemblage is key to my ecocritical reading of Chamoiseau's novel. With the transition of the Slave Old Man from living man to fossilized bone and his focus on the animal, vegetable, and mineral, Chamoiseau evokes the geontological. The force and meaning of the Slave Old Man does not vanish when he is no longer living. As bone, the Slave Old Man calls to the writer to create meaning through story. In the final chapter, Chamoiseau intimates how contact with the physical object of the Slave Old Man's bone inspires the author to write the text. In Le vieil homme esclave et le molosse, Chamoiseau provides archetypal examples of assemblage as understood by Povenelli. While the reader encounters many assemblages in the text, in the context of the geontological, I will focus on two specific assemblages. Both examples reinforce a physical and metaphysical connection between the African and the land including the original Indigenous inhabitants.

Firstly, one of the most striking and significant assemblages that concerns the living is the connection between Slave Old Man and the forest, the Grandsbois, where he seeks refuge. The non-habitation geographies of the island are largely unknown to Slave Old Man prior to his maronnage. He discovers the forest both physically and metaphysically even while he frantically attempts to outpace the molosse at his heels. This is not inconsequential. Intimate knowledge of the land is a foundational element in creating an ontological link between a people and their local environment in many Indigenous, non-Western societies and in the textual world of Le vieil homme esclave et le molosse. Slave Old Man uncovers the secrets of the forest as he flees the violence of the plantation, gaining awareness of botanical and zoological diversity as he travels farther away from the sugar cane monoculture of the settled areas of the island. This apprenticeship is articulated via a (re)awakening (évei) not only of the main character's understanding of the natural world, but also as a (re)awakening to his own corporality.

Through sensation, through his body being (re)humanized, Slave Old Man becomes aware of the intricate web of life around him. The author tells us that, "Ces Grands-bois avaient fasciné les nègres fugueurs. Ils s'y étaient réfugiés comme dans un ventre manman" (Chamoiseau, Le vieil homme esclave et le molosse Chapter 5). Not only do the plants and animals of the forest become alive for him, but also so-called non-living entities such as a spring where he and the molosse nearly drown. This is a geontological moment in the text. The spring is first perceived as a source of fear, metaphorically linked to the trauma of the Middle Passage. However, the description shifts to describe the spring as 
agentive, as a subject integral to the forest's well-being. The spring nourishes the vegetal entities that surround it. The life of the spring precedes that of the human presence on the island. Briefly sketching the biography (writing of life, bios) of the spring, Chamoiseau reveals that it has been a part of the forest for twenty-two thousand years (Le vieil homme esclave et le molosse Chapter 5). Traditionally viewed as non-life, the author's geontological portrayal of the spring attributes subjectivity and insists on its centrality in the life of the Grandsbois. Slave Old Man's forest apprenticeship culminates in an important narrative shift that signals symbiotic and symbolic integration of the African with the land.

Un total végétal d'un serein impérieux. Je. Les feuilles étaient nombreuses, vertes en manières infinies, ocre aussi, jaunes, marron, froissées, éclatantes, elles se livraient à de sacrés désordres. Je. Les lianes allaient chercher le sol pour s'emmêler encore, tenter souche, bourgeonner. Je pus lever les yeux et voir ces arbres qui m'avaient paru si effrayants dans leurs grands-robes nocturnes. Je pus les contempler enfin (Chamoiseau, Le vieil homme esclave et le molosse Chapter 5).

Chamoiseau utilizes the technique of free indirect discourse to announce that a fundamental change has occurred. First a relative stranger to the biota that he moves through, eventually Slave Old Man becomes incorporated into the forest and its teeming life (and non-life). It becomes familiar and familial. Chamoiseau insists on a vegetal connection that entails the achievement of reciprocity. Much like when the hound licks Slave Old Man's face as he lies dying, it is the nonhuman which demonstrates agency in the coming together of existents, in their act of becoming with. It is the imperious forest that conquers Slave Old Man, not the other way around. This is a key distinction, because the narrative shifts from the perspective of the Master, the molosse, and Slave Old Man underscore the uniqueness of Slave Old Man's experience vis-à-vis Nature. In contradistinction to the author's numerous descriptions of the extractive, exploitative relationship between the béké and the land, this relation is one of mutuality and inclusion.

Throughout the text leading up to this passage, the author employs thirdperson narration to recount the experiences of Slave Old Man. The abrupt switch to free indirect discourse, the sudden emergence of "je", connotes a deeper affiliation between the African and the land. In addition to this legitimized geographical joining together, a temporal boundary is also traversed via the writer's foray into first-person narration: Chamoiseau equally calls to his contemporary readership here to recognize a deeper understanding and identification between Slave Old Man and themselves. The literary project of the novel is diachronically inflected. It engages the readership with both a historical recounting (or perhaps rewriting) of slavery and resistance to it, as well as the present moment and its critical need to see the non-human world from a 
geontological viewpoint. That is to say, to recognize the intrinsic value in a much broader array of existents.

The emphasis on the first-person pronoun, the fact that it is set apart as a stand-alone sentence multiple times in this short passage calls attention to the shift, to the joining together of the African and the land, of the past and the present. Additionally, the process of assemblage finds expression in the color palette that the author attributes to the forest. The listing of colors includes a term with polysemic purchase within the context of the novel: marron. The diverse color spectrum of the forest that dazzles the eye from an ecological and esthetic point of view also carries the meaning of ontological aggregation, of joining together, of becoming with. Marron simultaneously refers to the color brown as an adjective describing the forest and to a noun, the runaway slave himself. Therefore, Chamoiseau situates Slave Old Man within the assemblage of the forest as an integral component of the natural environment of this particular locality, one component of the plural sacrés désordres that define the space as living. The author's employment of free indirect discourse in conjunction with the assemblage that fixes the African in a central position in the physical and metaphysical existence of the forest ecosystem anchors the African as a legitimate inhabitant of the land. This process of legitimization will reach its final culmination in the subsequent assemblage of the fossil bone of Slave Old Man and the stone inscribed by the original inhabitants of the land, the Caribs.

Immediately following the joining of African and land, the actions taken by the vines who seek out the soil, attempt to take root, and blossom are evocative of the African anchoring in Caribbean geographies as proposed by Chamoiseau. Physical integration in the landscape equally allows for metaphysical integration. The trees that were once a source of fear and uncertainty, now are invitingly robed and open to contemplation, to mutual understanding, albeit on an admittedly anthropomorphized footing. The symbiosis described between the African and the land is denied elsewhere in the novel to the béké. Earlier during the pursuit of Slave Old Man, the white plantation owner lags behind the advancing molosse and finds himself enveloped by the same forest, a foreign environment that differs greatly from the plantation to which he is used.

...le Maître se sent mal à l'aise, le bon-ange dérangé. Il prend conscience que les arbres murmurent pour de bon. Ils ne s'adressent pas à lui, mais ces murmures le concernent, tellement il les encaisse au clair même de son crâne... ...Le Maître se sent seul (Chamoiseau, Le vieil homme esclave et le molosse Chapter 4).

The ontological enfolding of the African into the forest is not possible for the béké. While the slaveowner notices the life in the forest. Its subjectivity is 
signaled in a fashion familiar to any reader of Chamoiseau, through orality. Orality (or the ability to speak) epitomize agency, existence, and community in Chamoiseau's oeuvre as a whole. The ambiguity of the verb 'concern' accentuates the békês lack of understanding vis-à-vis the geographies of the Caribbean. In this first example of assemblage, the aggregation of Slave Old Man with the natural world is a first step toward a more profound articulation of the legitimation of African belonging to Caribbean geographies in contradistinction to extractive capitalist relationships with the land as typified by what Chamoiseau refers to as the "la science esclavagiste" (Le vieil homme esclave et le molosse Chapter 2). A completely different interaction with the land and its multiple histories is entailed by the assemblage of Slave Old Man and the Amerindian stone that he encounters in the depths of the forest.

In this second assemblage, that between the fossil slave bone and the inscribed Amerindian stone, the joining together of African, Amerindian, and Caribbean geographies is completed. This assemblage focuses on the geontological, on the life in what is often categorized as non-life. Foreshadowed early on in the text, the juxtaposition of the fossil bone of Slave Old Man and the inscribed Amerindian stone is discussed as a diachronic disaggregation in the first pages of the novel. In this context, the arrival of the colonizers is signaled as the catalyst of much pain and suffering, later to be (re)assembled and ontologically aggregated in the assemblage of bone and stone.

Depuis l'arrivée des colons, cette île s'est muée en un magma de terre de feu d'eau et de vents agité par la soif des épices. Beaucoup d’âmes s'y sont dispersées. Les Amérindiens des premiers temps se sont transformés en lianes de douleurs qui étranglent les arbres et ruissellent sur les falaises, tel le sang inapaisé de leur propre génocide. Les bateaux négriers des seconds temps ont ramené des nègres d'Afrique destinés aux esclavages des champs-de-cannes. ...Désignons cette horreur : pièce de ces misères si souvent illustrées, mais le déshumain grandiose qui œuvre l'existant comme densité inerte, indescriptible (Chamoiseau, Le vieil homme esclave et le molosse Chapter 1).

This passage details Amerindian genocide, the Middle Passage, and subsequent chattel slavery from a historical perspective. The déshumain grandiose is a reference to the project of colonial capitalism and its obsession with sugar and spice. Chamoiseau's critique of that system and its constitutional acts of violence resides in his characterization of its ineffability. Loss of meaning adheres to the violence of both the first genocide of the Caribs and the second unspeakable reality of slavery. The desire and need to define the horrors of both are indicated in the collective imperative of 'désignons'. However, the attempt to interpret and represent this violence ultimately fails at this early stage of the narration, because in the final analysis it is 'indescriptible'. This representational impasse is echoed by the ontological disaggregation associated with the Middle Passage, discussed above. The entire novel grapples with this ineffability from 
multiple viewpoints, including those of the Master and the molosse. This primary disaggregation, the result of mass violence committed against the Amerindian and African peoples in the Caribbean is ultimately resolved in the text via the geontological technique of assemblage.

Chamoiseau explains to the reader at the beginning of the second chapter that bone is constitutionally adept at transcending the divide between life and the non-life at the center of geontological understandings of subjectivity and agency. This is clear in the passage, "Principe des os, minéral et vivant, opaque mais organisateur" (Chamoiseau, Le vieil homme esclave et le molosse Chapter 2). Bone represents a bridge between the world of the living and that of the non-living. Mineral and alive, bone transcends Western categorizations that would seek to relegate the non-living to the status-less, exploitable realm of the non-existent. The opacity, physical and metaphorical, refers again to the ineffability that Chamoiseau struggles to overcome in Le vieil homme esclave et le molosse. As object, it resists definition, but as (re)humanized living fossil, representing suffering and resistance to the violence that occasioned that suffering and death, this opacity is coupled with the potential to organize, to assemble. This epigraph to the second chapter foreshadows the (re)assemblage at the end of the novel, the joining of the African bone and the Amerindian stone, that will (re)assign meaning to the history of violence that initially precludes definition and expression.

The stone is ambivalent geontologically. Thwarting Western categorizations of non-life, the stone is related to the geological, not as mere passive object but as active agent and living entity.

Elle [la pierre] a grossi aux profonds de mer, comme un boulet verdi. Elle a roulé dans la faille atlantique où la chose inconnue palpite, elle a déplacé les plaques des continents, elle nous a fait trembler du tremblement de nos terres rouges, et c'est vrai, elle a enfanté le chien (Chamoiseau, Le vieil homme esclave et le molosse Chapter 6).

The actions of the stone are instrumental in the creation of the Caribbean geographies in the physical and metaphysical senses. Not only energetically involved in physical tectonics, the metaphysical mysteries of the underworld are at the origin of the stone's unique identity. Contributing creatively and destructively, the link to the community of the human and animal is evidenced in this description, as well. The earthquake and the bringing into the world of the molosse speak to the interconnectivity of all categories of existent including what is typically considered non-life, rock or tectonic shift, from a Western viewpoint. Chamoiseau's radical animist view of the stone goes beyond the human to include the geological and the animal worlds, granting value, meaning, and subjectivity to this singular mineral existent. 
Subsequently, Chamoiseau continues to elaborate on the significance of the rock by recounting the history of the original Carib inhabitants of Martinique through the dreaming of the stone. The stone that Slave Old Man discovers (or recovers in the archaeological sense of the term) is a powerful tool wielded in Chamoiseau's hands for the creation of meaning and legitimacy. The etchings and markings on the stone, which parallel the role of author in the context of this particular writer's self-positioning as marqueur de paroles, are enunciated through the action of dreaming. Perhaps not surprisingly, it is not Slave Old Man who dreams in this instance, but the stone itself. "La Pierre rêve" (Chamoiseau, Le vieil homme esclave et le molosse Chapter 6). The choice of dreaming as vehicle of history is anything but anodyne. By emphasizing dreaming, Chamoiseau insists upon the inner life or (sub)consciousness of the mineral. Along the same lines, the agency and subjectivity of the stone is reinforced through naming; it appears textually as la Pierre. In addition to the polysemy of the word as both object and proper name (with specific religious connotations in the Christian tradition), the titular capitalization of the term buttresses the existent's status as agentive subject.

The migratory history of the arrival of the Carib Indians on the island of Martinique from the South American continent is expressed through the stone's dreaming. In addition to the worried movements that instigated the move from the mainland, the quotidian life of the Caribs resides in the stone, as well. Having been linked both to the geographies and original peoples of the Caribbean, the joining together of these geontological and animist subjectivities finally includes the African through orality and shared dreaming.

Le Pierre rêve. Elle m'engoue de ses rêves. Je me serre contre elle, la main avide. Mon esprit abandonne ses marques. Il est possible que je lui parle, que moi je parle à une pierre. Ou rêve avec elle. Oui, nos rêves s'entremêlent, une nouée de mers, de savanes, de Grandes-terres et d'îles, d'attentats et de guerres, de cales sombres et d'errances migrantes sur cent mille fois mille ans. Une jonction d'exils et de dieux, d'échecs et de conquêtes, de sujétions et de morts. Tout cela, grandiose hélée, tourbillonne dans un mouvement de vievie en vie sur cette terre. La Terre. Nous sommes toute la Terre (Chamoiseau, Le vieil homme esclave et le molosse Chapter 6).

Slave Old Man's hand seeks to understand the markings, only to give up on the endeavor in favor of orality. The conversation with the stone indicates a mutually reciprocal understanding and being, a regard for one another, an intercommunication, becoming with via dreaming with. This is a crucial geontological and animist event. The living stone speaks to and through the living African man. The possibility of speaking with a rock is the possibility of the geontological in opposition to the extractive, the anthropocentric, and the biopolitical. This insistence on life, on the stone's subject status as equal 
interlocutor, is an example of the geontological redolent of Povinelli's work on Aboriginal ontologies. Povinelli posits three possible paths for including the non-human or non-life into the demos, into the political or the polis:

One extends the features of human language (speech) to all things. Another refigures semiosis as a broad mode of sign production and interpretation that can be extended to all living things. And a third that figures all things as aspects of assemblages with the power to animate a response-to initiate an event (Povinelli, "The Rhetorics of Recognition in Geontopower" 440).

In this triumvirate, orality and assemblage are joined by an expanded conception of semiotics and the possibilities for the creation of meaning and value, one which includes all (living) things. All three modalities are present in Chamoiseau's radical animism with the culmination of assemblage and subjectivity here in the geontological vein. The voice that speaks in the stead of the assemblage imbues subjectivity throughout the various categorizations of life and non-life. The new articulation of a geontological 'we' in the political realm is figured in the transition from 'terre' with a lower-case ' $T$ ' to the allinclusive 'Terre' with an upper-case 'T', “Tout cela, grandiose hélée, tourbillonne dans un mouvement de vie_-vie en vie sur cette terre. La Terre. Nous sommes toute la Terre" (Chamoiseau, Le vieil homme esclave et le molosse Chapter 6). Including the entirety of Earth, life and non-life, human and non-human alike in an assemblage of meaning and political subjectivity and status is an essential starting point for engaging seriously with the complexity of the global climate crisis. Until 'we' includes all that has heretofore been affixed with the label of 'it', there can be no global climate politics equal to the task.

\section{Conclusion}

In the conclusion to a text that has become recognized over the last three decades as a seminal work of French ecocriticism, Michel Serres speaks to the same question of politicizing non-life, of returning to an ontological (or geontological) mutuality that admits the Earth in the parliament of things. The parliament of things being a Latourian concept that rightly identifies the crux of the geontological dilemma, "The problem was never that nonhumans did not speak, but that they were forced to speak only in one way, namely as mere passive objects" (Simons 15). Serres' monograph Le contrat naturel does the same work taken up by Chamoiseau's radical animism and Povinelli's insistence upon the geontological and the assemblage as the measure of subjectivity. Serres calls for the inclusion of the non-human, of non-life into the conversation of what Rousseau and Hobbes theorize as the social contract. Replacing divine-right, sovereignty has since the birth of the nation-state been uniquely attributable to anthropos in keeping with Rousseau and Hobbes' articulation of political power. Serres insists on the right of non-life, as well as all categories of Life, to be 
accorded the right to sign the contract founding a new sovereignty to ensure our shared future. Admitting humanity's inability to differentiate infallibly on the geontological questions raised by Povinelli, Serres tells us that, "Ces liens de symbiose, réciproques tellement que nous ne savons dans quel sens va la naissance, dessinent le contrat naturel" (189). Our inability to distinguish between the transitional, between birth and death, opens a space for the geontological to gain the status of equal interlocutor through the event of assemblage.

To return to Chamoiseau's Le vieil homme esclave et le molosse, Western perspectives would deem both the Amerindian stone and Slave Old Man's fossil bone as non-life, and therefore without agency, subjectivity, or intrinsic value. This classification denies juridical status to both through the designation of dead or non-living. Chamoiseau's articulation of radical animism rejects the reductive dispensation of late liberal capitalism, forged in the genocides of contact with the Western Hemisphere and the colonial histories of slavery, in favor of a transcendent joining together and becoming with that seeks to incorporate the entire planet, granting the status of living, of agentive subjectivity to all existents. In this way, Chamoiseau conveys a critical message about how the earth should be regarded from a geontological point of view. Going beyond the energy of critical attacks on the anthropocentric biopolitical, the author's ecocritical directive aims at the geontological underpinnings of the extractive economies that despoil the human, the animal, the vegetal, and the mineral alike. Late liberal capitalism's indiscriminate devaluation of existents is replaced through Chamoiseau's radical geontological animism with a call (a grandiose hélée) to recategorize all existents as subjects, as agents, as life rather than non-life. The decategorization of non-life status as effectuated through the extreme application of neoliberal market principles has tipped an ever-increasing majority of existents into the bin of expendability. The decreasing power of the nation-state with its concomitant erosion of protections and safeguards for all existents has increased the precariousness of the very existence of the earth itself. In Le vieil homme esclave et le molosse, Chamoiseau seeks to rehumanize the victims of genocide and slavery, but also to revalorize all forms of existence through a radical animism that participates in the discursive shifts that Povenelli labels the geontological. Through assemblage Chamoiseau tells us we can 'animate a response' to the most critical issue of our times. 


\section{Bibliography}

Allen, Chadwick. Trans-Indigenous: Methodologies for Global Native Literary Studies. University of Minnesota, 2012.

Barnabé, Jean, et al. Éloge de la créolité: In Praise of Creoleness. Gallimard, 1990.

Chamoiseau, Patrick. "Prologue: Globalization, Globality, Globe-Stone". Caribbean Globalizations: 1492 to Present Day, edited by Eva Sansavior and Richard Scholar, Liverpool University, 2015.

Chamoiseau, Patrick. Le vieil homme esclave et le molosse. Kindle ed., Gallimard, 2016.

Descola, Philippe. Par-delà nature et culture. Kindle ed., Gallimard, 2015.

Ghosh, Amitav. The Great Derangement: Climate Change and the Unthinkable. Kindle ed., The University of Chicago, 2016.

Haraway, Donna J. When Species Meet. University of Minnesota Press, Minneapolis, 2008.

Huggan, Graham and Helen Tiffin. Postcolonial Ecocriticism: Literature, Animals, Environment. Kindle ed., Routledge, 2015.

Povinelli, Elizabeth, A. Geontologies: A Requiem to Late Liberalism. Kinde ed., Duke University, 2016.

Povinelli, Elizabeth, A. "The Rhetorics of Recognition in Geontopower". Philosophy and Rhetoric, vol. 48, n 4, 2015, pp. 428-442.

Serres, Michel. Le contrat naturel. François Burin, 1990.

Simons, Massimiliano. "The Parliament of Things and the Anthropocene: How to Listen to 'Quasi-Objects"'. Techné: Research in Philosophy and Technology. vol. $21, \mathrm{n}^{\circ} 2-3,2017$, pp. 1-25. 